DOI: https://doi.org/10.30525/978-9934-26-020-9-12

\author{
Nina Dorosh \\ Doctor of Economics Sciences, Professor, \\ Professor of Accounting and Auditing Department \\ Taras Shevchenko National University of Kyiv
}

\title{
ESSENCE AND PRINCIPLES OF CORPORATE GOVERNANCE
}

\section{Summary}

The article reveals the essence of corporate governance and its purpose to ensure the economic efficiency of the enterprise, the balance of interests of participants in corporate relations, financial transparency and the introduction of rules of adequate management and proper control. According to the concept of the agency and the content of corporate governance, the participants involved in the management of enterprises and their functions are defined. The provisions of legislative and regulatory acts, in particular the principles of effective corporate governance, are covered. The basic principles of proper and effective corporate governance in the banking sector of the economy are named and analyzed, considering its features.

\section{Introduction}

In modern economic development, one of the main factors influencing the successful operation of economic entities is the organization and implementation of effective corporate governance to promote economic efficiency, sustainable growth and financial stability, proper protection of investors' rights, reliable management and control mechanisms, openness and transparency in their activities. Today, many countries see corporate governance as an integral part of a market economy, a condition for the development of effective entrepreneurship, a mean of increasing competitiveness in international markets and improving economic performance in general. Businesses with weak management and corporate governance seem like risky investments for investors.

In today's market environment, one of the main factors influencing the successful operation of the enterprise is the ability to attract investment resources. At the same time, an enterprise cannot count on investors' trust and external financing if it does not take measures to implement effective corporate governance, specifically, proper protection of investors' rights, reliable management and control mechanisms, openness and transparency in its activities. The corporate governance system is an organizational model through which the company represents and protects the interests of its investors. 
In order to increase the economic efficiency, sustainability of the business entity and build an effective and adapted to threats corporate governance system, it is necessary to solve a number of problems:addressing the factors of uncertainty and instability of the external socio-economic environment, improving corporate law and corporate governance principles, corporate policy of the enterprise taking into account the development strategy and interests of all stakeholders, professional duties and responsibilities of all participants in the corporate governance process, adaptation of management approaches to all the complexities of doing business and trends in the modern economy, etc.

\section{Part 1. The essence of corporate governance and the theory of agency}

Enterprise management is the process by which owners and shareholders exercise control and accountability for the resources entrusted to them. Owners elect a board of directors to provide supervision over the activity of the enterprise and report to them. The main goal of the board of directors should be to build long-term sustainable growth of the company's shareholder value. Effective business management depends on successful managers, as they have the greatest responsibility for building a corporate culture, acting together and adhering to professional and ethical behavior. Good corporate governance should be in line with the company's strategy and not be seen as a mere obligation.

Corporate governance determines how the corporation's shareholders exercise control over the activities of management, as well as the responsibility of the company's leaders to shareholders for the results of their activities. In today's crisis, the issue of obtaining reliable information about the state of affairs at enterprises in order to make effective investments is especially relevant.

The Organization for Economic Co-operation and Development determines that corporate governance includes a system of relationships between the company's management, its board of directors, shareholders and other stakeholders. Corporate governance also provides a framework for setting company goals, ways to achieve them, and monitoring performance [4].

The Basel Committee on Banking Supervision provides the following definition of corporate governance. Corporate governance is a set of relationships between the company's management, its board, its shareholders and other stakeholders, which provides a structure through which to define the company's goals, ways to achieve these goals, as well as monitoring performance. Helps to determine the method of distribution of powers and responsibilities, as well as the method of corporate decision making [12].

According to the concept of agency, the management of corporate structures is carried out by directors, who are appointed by the owners, shareholders. Directors formulate a corporate strategy to achieve their goals 
and meet market needs, and, in turn, hire managers and staff to implement this strategy [14, p. 22].

Management (managers) carry out business activities with the help of hired staff - employees of the corporation. This means that hired managers are agents of the owners, shareholders of the corporation. The latter act as principals, so there are agency relationships when agents act on behalf of the principal [6, p. 185].

To achieve the stated goals, directors put of tasks for their team of managers, approve the budget, resources, and determine the mechanism for evaluating performance. While owners-shareholders delegate responsibilities and authority to various parties in the company, they require accountability and reporting on how effectively trusted resources are used by managers and the board of directors. All business activities are reflected in the reporting system, according to which directors report to shareholders on the results of their activities. Shareholders constantly check the overall performance and financial results to ensure the effectiveness of the activity, the growth of the value of their investments due to the high share price, as well as to receive dividends.

However, senior management is obliged to take all necessary measures to protect business and record their activities. The concept of responsible management means that directors are responsible to the parties who have a personal interest in the company. They work for and on behalf of their owners and must demonstrate competence in the performance of their duties.

The final financial statements of the company are subject to audit by an external audit firm to confirm the actual financial condition and results of operations. The results of the inspection are provided to the owners, shareholders.

Many parties have a legitimate interest in the management of the enterprise, these are: shareholders / owners; board of directors; audit committee (subcommittee of the board of directors); management (financial and operational); internal auditors; self-regulatory organizations; regulatory bodies, regulators; external auditors.

The general process of enterprise management is schematically presented in Figure 1.

Management begins with shareholders / owners delegating responsibilities through an elected board of management, which in turn delegates them to operational units with oversight and the assistance of internal auditors. The Board of Directors and its Audit Committee supervise the work of the management and, based on this role, protect the rights of shareholders. In addition to shareholders, the board of directors and managers is also accountable to other stakeholders. The main group of stakeholders is interested in the quality of enterprise management, as it has relationship with economic productivity and the quality of financial reporting. The term society in fig. 1 is used to determine his interests. Managers and the board of directors 
are accountable to the public for compliance with the law, and must meet the requirements of creditors and employees and other stakeholders. Employees and creditors have a legitimate interest in how the business is managed. Regulators are accountable to the public to ensure that the company acts responsibly, reliably and in compliance with the law in pursuit of the achievement of the owners' goals.

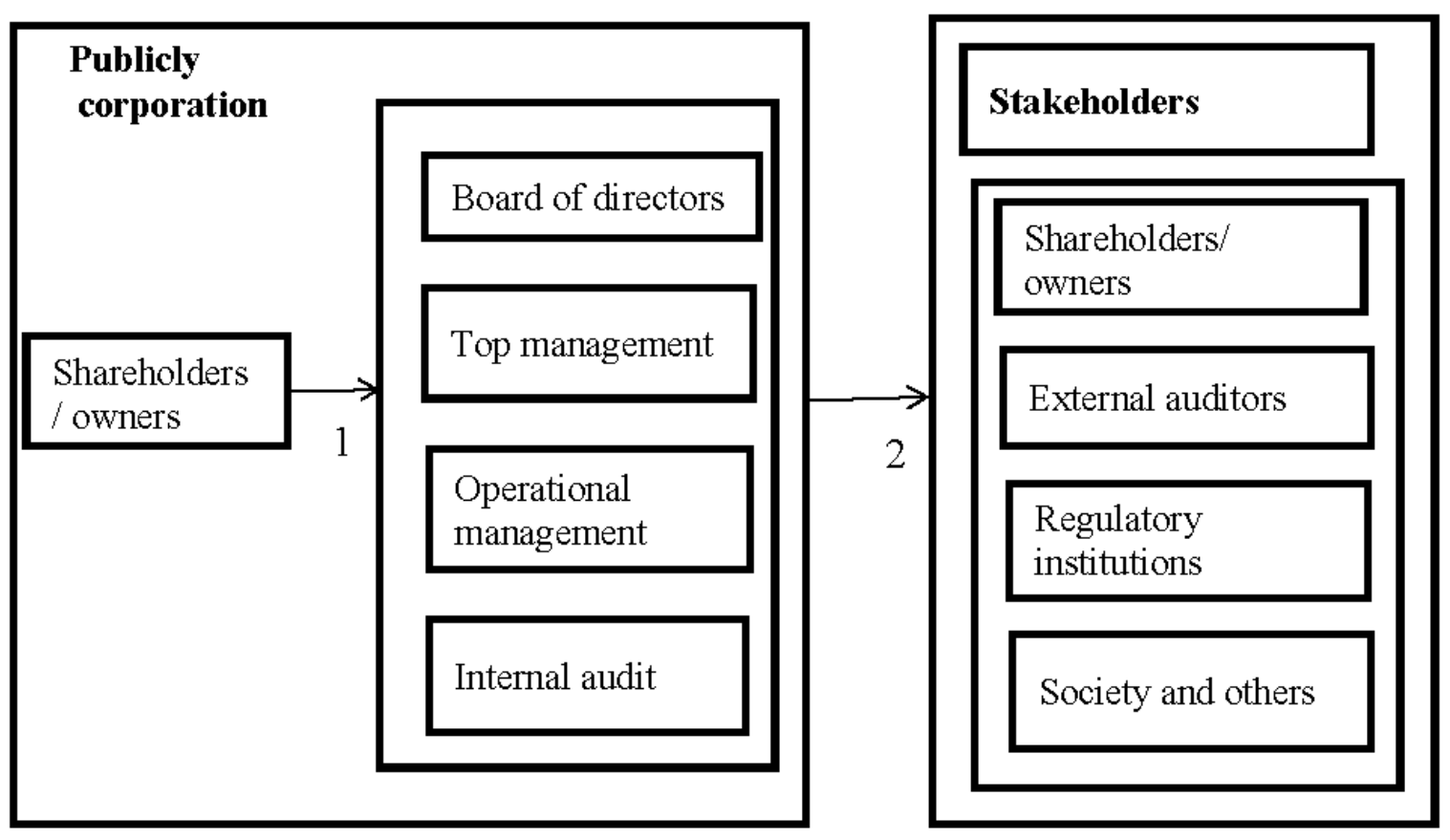

Figure 1. Overview of business management responsibilities and liabilities

1- Empowerment

2- Are responsible to

Source: created by the author for $[1, p .44]$

Owners want managers to provide accurate and objectively verified disclosures. They seek to have information on the following aspects: financial indicators, performance indicators; financial transparency - financial statements that are reliable and fully disclose and reflect the financial, social and environmental status and performance of the enterprise; property management, including information on how the company uses the resources provided to it; quality of internal control; the composition of the board of directors and the nature of their actions, including information on how wellmanaged incentive systems promote the interests of stakeholders.

One of the main tools used to achieve effective corporate governance is the introduction of principles (codes) of corporate governance.

Today, many countries see corporate governance as an integral part of a market economy, an essential condition for the development of private 
enterprises, a mean of increasing competitiveness in international markets and improving economic performance in general. Improving corporate governance at the national level has become an important area of effort for many countries. At the same time, solving the problems of corporate governance as an important factor of national development is insufficient in the conditions of international competitive environment and requires their settlement through the introduction of international norms of corporate governance practice. The development and legislative establishment of international standards and rules to be implemented in the practice of enterprises, ultimately guarantees to potential investors the reliability of their investments, allows them to obtain complete and objective information about the entity's activities.

The emergence of international standards of corporate governance is primarily due to the growing attention to corporate governance in the context of globalization of financial markets, liberalization of capital movements. It is an attempt to establish generally accepted, transparent and understandable worldwide «rules of the game» in the financial market. The development of international standards of corporate governance is also society's response to global financial crises and the pursuit of financial market stability.

It should be noted that synonym for management is control. The globalization of governance processes has the worldwide extent in society. Together with international accounting standards, we are approaching an era of closer interconnectedness in all developed and developing countries, as well as the use of corporate governance principles, which are mandatory for the Organization for Economic Co-operation and Development (OECD), as it has global context [14, p. 46].

Although there is no single model of corporate governance in the world, there are generally accepted principles (standards) that underlay effective corporate governance and can be applied in a wide range of legal, economic and political conditions of countries around the world.

\section{Part 2. Principles of corporate governance}

The G20/OECD (Organization for Economic Co-operation and Development) principles of corporate governance [4], first adopted in 1999, have become an international guideline in the field of corporate governance. The G20/OECD Principles of Corporate Governance are designed to help policy makers evaluate and improve the legal, regulatory and institutional framework for corporate governance. They also contain guides for stock exchanges, investors, corporations and others who play a role in the process of forming good corporate governance.

These principles also emphasize that corporate ethics and social interests can affect a company's reputation and have an impact on long-term success in attracting investors and keeping, maintaining existing capital through clear, understandable and accessible conditions. The OECD recognizes that there is 
no single good model of corporate governance and principles are evolving and changing along with innovations in corporations. The following principles of corporate governance are key: providing a basis for an effective corporate governance structure; shareholder rights, equal treatment of all shareholders and key ownership functions; institutional investors, securities markets and other intermediaries; the role of stakeholders in corporate governance; information disclosure and transparency; duties and responsibilities of the board of directors (Table 1).

Table 1

\section{Principles of OECD corporate governance}

\begin{tabular}{|l|l|}
\hline \multicolumn{1}{|c|}{ Principle } & \multicolumn{1}{c|}{ The content of the principle } \\
\hline $\begin{array}{l}\text { Providing the } \\
\text { foundation for } \\
\text { effective CG }\end{array}$ & $\begin{array}{l}\text { The corporate governance structure should promote transparent and } \\
\text { fair markets and the efficient allocation of resources. It should meet } \\
\text { the requirements of the rule of law and support the effective } \\
\text { supervision and application of the law. }\end{array}$ \\
\hline $\begin{array}{l}\text { Fair treatment of } \\
\text { shareholders }\end{array}$ & $\begin{array}{l}\text { The corporate governance structure should protect shareholders' } \\
\text { rights and ensure fair and equal treatment of all shareholders, } \\
\text { including minority and foreign shareholders. }\end{array}$ \\
\hline $\begin{array}{l}\text { Institutional } \\
\text { investors, securities } \\
\text { markets and other } \\
\text { intermediaries. }\end{array}$ & $\begin{array}{l}\text { The corporate governance infrastructure should provide } \\
\text { appropriate, reasonable incentives throughout the investment chain } \\
\text { and make the securities markets to function in such a way as to } \\
\text { promote good corporate governance. }\end{array}$ \\
\hline $\begin{array}{l}\text { The role of } \\
\text { stakeholders in CG. }\end{array}$ & $\begin{array}{l}\text { The structure of the CG should recognize the rights of stakeholders } \\
\text { under the law or multilateral agreements and encourage active } \\
\text { cooperation between corporations and stakeholders to create } \\
\text { prosperity, jobs, and financially sustainable enterprises. }\end{array}$ \\
\hline $\begin{array}{l}\text { Disclosure and } \\
\text { transparency of } \\
\text { information }\end{array}$ & $\begin{array}{l}\text { CG infrastructure should provide timely and accurate disclosure of } \\
\text { all material matters regarding the corporation, which includes the } \\
\text { financial condition, results of operations, distribution of ownership, } \\
\text { structure and policy management, annual audit report, and access } \\
\text { to that information for users. }\end{array}$ \\
\hline $\begin{array}{l}\text { Responsibilities of } \\
\text { the board of } \\
\text { directors. }\end{array}$ & $\begin{array}{l}\text { CG structure should provide strategic management of the } \\
\text { company, effective control and monitoring of management on the } \\
\text { part of the board of directors and board accountability to the } \\
\text { company and shareholders. The board must have access to all } \\
\text { information about the company, treat shareholders fairly, ensure } \\
\text { compliance with the law, have an appropriate internal control } \\
\text { system, including a risk monitoring system, and information } \\
\text { disclosure and communication processes. }\end{array}$ \\
\hline
\end{tabular}

Source: developed by the author

An important principle of corporate governance is accountability. The Board of Directors is authorized to act on behalf of the company. Therefore, it has to assume full responsibility for those powers delegated to it and which it carries. Corporate accountability is understood as responsibilities, among which to provide explanations and justify the actions and behavior of the 
enterprise. Namely, the board of directors must: present, provide a balanced and clear assessment of the position and prospects of the enterprise; be responsible for determining the nature and level of significant risks to which it is willing to take; maintain smart risk management and internal control systems; establish formal and transparent mechanisms for corporate reporting and risk management, in particular, to maintain proper relationships with the company's auditors; communicate regularly with stakeholders to obtain a fair, balanced and understandable assessment of the company's performance [3].

In order to gradually approximate Ukrainian legislation to the rules and recommendations of the European Union and take into account the Principles of Corporate Governance of the OECD (Organization for Economic Cooperation and Development), the National Commission on Securities and Stock Market (NSSMC) on March 12, 2020, adopted Decision No. 118»On approval of the Principles of corporate governance «.This document contains important updated recommendations for quality and transparent management of the company, compliance with which should help increase company's their investment attractiveness and competitiveness.

Figure 2 shows the basic principles of corporate governance, compliance with which will allow joint-stock companies to achieve greater attractiveness from shareholders and investors, increase the level of competitiveness and solvency.

The importance of the banking system for the country's economy and its specific characteristics determine that the banking system in most countries of the world is subject to strict regulation by the state and special supervisors. Corporate governance in a bank is a process that is carried out in order to ensure the efficient operation and reliability of the bank, as well as to increase its value. It includes of creating a system of corporate relations, which contributes to the balance of influence and balance of interests of shareholders, depositors, management, and employees of the bank, as well as other stakeholders.

The primary purpose of corporate governance must be a sustainable maintenance of compliance between stakeholders' interest and state interest. Among the stakeholders, in particular, regarding retail banks, the interest of shareholders will be minor compared to the interest of depositors [12, p. 5].

The Basel Committee on Banking Supervision has developed thirteen basic principles for sound and effective corporate governance in banks: the general responsibilities of the board; qualification and composition of the council; structure and methods of work of the council; senior management; management in group structures; risk management unit; risk identification, monitoring, and control; notification of risk information; compliance with norms; internal audit; remuneration; disclosure and transparency of information; the role of supervisory authorities. 


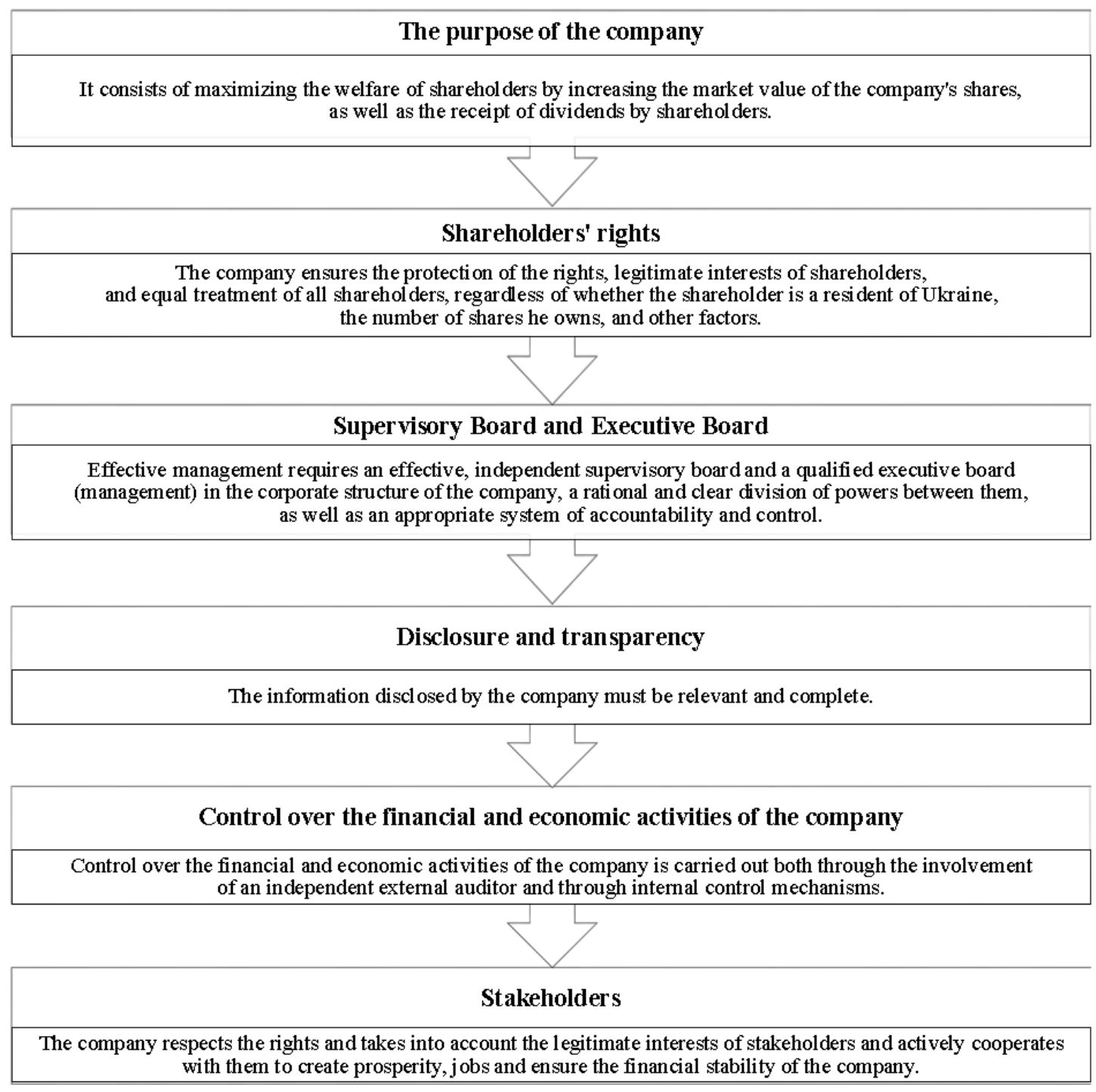

Figure 2. The principles of corporate governance

Source: created by the author

In general, the banking sector is characterized by higher risk compared to other activities. This feature is due to the specifics of the functions performed by each commercial bank. The bank's activities are very diverse and include operations to raise funds, issue and purchase securities, issue loans, factoring, leasing, providing customers with cash, and more. Despite the fact that banking activities is accompanied by numerous risks, the banks are aimed to embody reliability and security. Since bankers work mostly with other people's borrowed money, they should try to reduce the risk of their activities even more than other entrepreneurs. Thus, risk management is considered as one of the main areas of banking management.

In this regard, the following principles of corporate governance in banks, which relate to risk management: risk management unit; risk identification, monitoring, and control; reporting of risk information. To implement them, 
banks must have an independent functioning risk management unit with the appropriate status, independence, resources, and the ability to interact with the board. Risk identification, monitoring, and control should be carried out constantly at the level of the bank and its individual divisions. Risk management and internal control infrastructure need to be improved. Effective risk management principles require effective dissemination of risk information in the bank between different departments of the organization, as well as by reporting to the board and senior management.

In accordance with the Regulations on the organization of risk management system in banks of Ukraine and banking groups, approved by the NBU Board Resolution № 64 of 11.06.2018 [10], the bank creates a comprehensive, adequate and effective risk management system taking into account the specifics of its activities, nature, and scope of its operations, risk profile and systemic importance of the bank, which meets the following principles: efficiency; timeliness; structure; delimitation of responsibilities (separation of the control function from the bank's operations); comprehensiveness and complexity; proportionality; independence; confidentiality; transparency.

Conducting each bank operation is associated with the possibility of occurrence of several risks. Increased bank risks can lead to significant financial losses and, as a consequence, to the bankruptcy of banks.

Because risk-taking is the basis of banking, banks succeed when the risks they take are justified, controlled and within their financial capabilities and competencies. Since it is impossible to completely avoid risks, they can and should be consciously managed, remembering that all types of risks are interrelated and their level is constantly changing under the influence of dynamic external and internal environments.

Risk management is considered as one of the important areas of corporate governance in the bank. Considerable attention is paid to studying risk areas and main types of risks, searching for effective methods of monitoring, assessment, analysis and control of banking risks, as well as the creation of appropriate management systems.

The bank carries out a significant number of banking operations and the each one is accompanied by the possibility of occurrence of several types of risks, so the effectiveness of risk management largely depends on the correct identification and assessment of a particular type of risk.

It is obvious that the existence of various types of risk leads to the need for their classification, proper selection and priority consideration during operations. Credit risk, liquidity risk, interest rate risk, market risk, currency risk, legal risk, operational and technological risk, reputation risk and strategic risk stand among the main banking risks. These types of risks are not mutually exclusive. Any bank product or service can expose a bank to several risks at once.

The risk of insolvency is important - as the probability that the bank will not be able to fulfill its obligations even in the case of the rapid assets realization (sale). Insolvency risk is closely related to liquidity risk and 
bankruptcy risk and is derived from other types of risks. That is why the process of corporate governance is based on constant control over the level of overall risk assumed by the bank.

The risk of reputation loss is caused by the possible inability of the bank to maintain its reputation of a reliable and efficient institution. The high level of dependence on borrowed funds makes banks particularly vulnerable to this risk. Loss of trust to the bank by depositors can lead to an outflow of funds and insolvency. The bank's management should pay special attention to compliance with regulatory requirements, constant monitoring of liquidity and the overall level of risk of banking operations.

As banking operations in most countries are the subject to strict regulation of state and special supervisory authorities, the bank is exposed to external risks, some of which, such as the risk of non-compliance with government regulations, are of a prior importance in the banking sector.

Enterprise risk management is a process carried out by the Board of directors, managers and other employees, which begins with the development of entity's strategy and regards all its activities. It is designed to identify events that may affect the enterprise and risks associated with these events, as well as to control that the entity's «risk appetite» is not exceeded while providing a reasonable guarantee of achieving it's goals [8, p. 124].

The bank should create a risk management system that provides detection, measurement (assessment), monitoring, reporting, control and mitigation of all significant risks of the bank in order to determine the amount of capital required to cover all significant inherent risks (internal capital). It should provide continuous risk analysis in order to make timely and adequate management decisions to mitigate risks and reduce associated losses.

The bank organizes a risk management system based on the allocation of responsibilities between the bank's units using the model of three lines of protection:

- the first line - at the level of the bank's business units and the bank's support units. These units accept and are responsible for risks and report on the ongoing management of such risks;

- the second line - at the level of the risk management unit and the compliance control unit;

- the third line - at the level of the internal audit department to verify and assess the effectiveness of the risk management system.

The main subjects of the bank's risk management system are: the Board of the bank; risk management committee of the bank's Board (if any); risk management unit; internal audit department; compliance unit.

The Board of the bank is fully responsible for creating a comprehensive, adequate and effective system for managing risks to which the bank is exposed in its activities.

In order to ensure the effectiveness of the risk management system, the risk management committee performs the following functions, among others: 
develops, ensures the development and/or participates in the development of internal bank risk management documents; monitors the status of implementation of measures to promptly eliminate deficiencies in the functioning of the risk management system, implements recommendations and comments of the internal audit department, external auditors, the National Bank and other supervisory authorities; monitors that the pricing/setting of tariffs for bank products takes into account the bank's business model and risk management strategy; ensures the performance of other functions on risk management issues determined by the bank's Board.

The Board of the bank itself performs the functions of the risk management committee, if it has not established such committee.

Methodical recommendations for improving corporate governance in Ukrainian banks, which was approved by the decision of the Board of the NBU № 814-rsh from 03.12.2018, created on the basis of the Laws of Ukraine «On the National Bank of Ukraine», "On Banks and Banking», in accordance with the updated principles of the Basel Committee on Banking Supervision to improve corporate governance in banking institutions and the Principles of Corporate Governance of the Organization for Economic Cooperation and Development.

Issues of improving the efficiency of the Board of directors and ensuring control over this body, which represents the interests of all shareholders in general, over the company's activities and its management make the basis of corporate governance codes.

In accordance with the principle of corporate governance «structure and methods of work of the council», the council must define and implement an appropriate management structure and methods of work and periodically check their effectiveness. The establishment of committees of the Supervisory Board, which deal with certain issues of its activities, significantly increase the efficiency of the Supervisory Board. The Supervisory Board Committee is an important tool that allows a small group of board members to pay attention to specific issues and use their expertise to address them. It is expedient to establish an audit committee in the bank, which supervises the system of internal control, reliability of financial statements, internal and external audit of the bank, compliance with the current legislation of Ukraine and internal procedures of the bank (compliance) and other problems identified by internal and external auditors. Given that the ultimate responsibility for overseeing the bank's risk management process rests with the supervisory board, it may form a risk management committee. Given the small composition of supervisory boards in Ukrainian banks, the functions of this committee may be delegated to the audit committee of the supervisory board. The Bank's Supervisory Board may also consider establishing a corporate governance and appointment committee.

One of the important aspects of each bank's functioning is internal control over its financial and economic activities, because it is an effective control system that should help preserve and rationally use financial, monetary and 
material resources of the bank, ensure accuracy and completeness of accounting records, maintain transparency and reliability of financial statements, prevent and detect falsifications and errors, ensure the stable and efficient operation of the bank, as well as the timely elimination of certain risks that threaten the achievement of its goals.

The Supervisory Board (through the audit committee of the Board) ensures the functioning of proper control system, as well as the implementation of strategic control over the financial and economic activities of the entity.

The audit committee of the Supervisory Board (audit committee) is established for the purpose of resolution of issues related to control and regulation of bank's activities in the field of financial reporting, internal control, internal and external audit.Tasks of the audit committee include: monitoring the integrity of financial information provided by the bank; consideration of the effectiveness of internal audit and internal control system; providing recommendations to the Board on the selection of an external auditor (audit firm) and the terms of the contract with them, etc.

Internal audit is an important effective tool that qualitatively increases the level of corporate governance, ensures stable development of an entity and maintaining a high competitive position in the business environment.

The essence of internal audit is defined in ISPPIA2100 «Nature of work» as: using a systematic and consistent approach, the internal audit activity must evaluate and contribute to the improvement of the organization's governance, risk management and control. The value and credibility of internal audit increases when internal auditors are proactive and their assessments contain new insights and consider future impact [5].

Internal audit in the corporate governance system is an integral part of the overall system of control by the Supervisory Board over the implementation of corporate strategy by the executive bodies (Board).

The internal audit department is an important body that establishes internal control procedures and prevents executive bodies from violating internal control and falsifying reports on the bank's financial and economic activities. It ensures the availability, evaluates the effectiveness and adequacy of risk management systems, internal control, corporate governance processes of the bank, compliance of these systems and processes with the types and volumes of operations performed by the bank, including prevention of the banking system from money laundering/terrorism financing.

One of the important modern functions of internal audit, established in the International Standards for the Professional Practice of Internal Auditing, is to assess and promote the effectiveness of the corporate governance system of the entity. According to ISPPIA 2110 «Governance», the internal audit activity must assess and provide appropriate recommendations to improve the corporate governance process.

Internal audit of organization's governance assesses the effectiveness of key components of corporate governance in terms of achieving the bank's 
development strategy, identifying strengths and weaknesses of existing corporate governance practices to meet strategic goals and objectives, preparing specific recommendations for improving corporate governance and its main components.

\section{Conclusions}

The purpose of corporate governance is to ensure the implementation of strategic goals and objectives of the enterprise, economic efficiency, and financial stability, balance of interests of corporate participants, transparency and openness of information, the introduction of rules of adequate management and control, building corporate culture and ethical behavior. According to the concept of the agency, the management of corporate structures is carried out by the board of directors, which are appointed by the owners and shareholders. They formulate a corporate strategy to achieve the goals, as well as, in turn, hire directors (managers) and staff to implement this strategy and are accountable to shareholders, owners.

To ensure high-quality management of the enterprise it is necessary to adhere to the principles of corporate governance, which are aimed at various aspects of management and actions of its participants. The G20 / OECD Corporate Governance Principles have become an international guideline in the field of corporate governance for stock exchanges, investors, corporations, and other businesses. The National Commission on Securities and Stock Market of Ukraine has approved updated Corporate Governance Principles, which are based on the OECD Principles of Corporate Governance and contain recommendations on quality and transparent governance, in order to increase investment attractiveness and competitiveness.

Models and principles of corporate governance are evolving and changing along with the trends of the modern economy and doing business, innovations in legislation, and corporate relations.

The peculiarities of the banking system and its importance for the country's economy determine the specifics of the principles of corporate governance, especially in relation to the sustainable compliance between interests of stakeholders and the state interest. Among stakeholders, in particular, regarding retail banks, the interest of shareholders will be secondary to the interests of depositors. The Basel Committee on Banking Supervision has developed the basic principles of reliable and efficient corporate governance in banks. Guidelines for improving corporate governance in Ukrainian banks have been developed in accordance with the updated principles of the Basel Committee on Banking Supervision and the OECD Principles of Corporate Governance.

As the banking sector is characterized by high risk in carrying out operations, risk management is considered to be one of the main areas of bank management. The bank shall establish a risk management system that 
identifies, evaluates, monitors, reports, controls and avoids, accepts, transfers or minimizes all significant risks for the bank in order to perform effectively.

Internal audit is an important and effective tool that qualitatively improves the level of entity's corporate governance, ensures the stable development of the bank and its maintenance of high competitive positions in the business environment. The internal audit activity must assess and provide appropriate recommendations aimed at improving the processes of corporate governance, risk management and internal control system, considering the strategy, objectives and risks of the bank.

\section{References:}

1. Auditing / Audrey A. Gramling, Larry E.Rittenberg, KariaM.Johnstone. $8^{\text {th }}$ ed. South Western, CengageLearning,2012. 1034 p.

2. Bevz O. Reform of corporate governance in banks. Seminar «Modern approaches to banking regulation and supervision in Ukraine». 2018. URL: https://bank.gov.ua/ doccatalog/document?id=69900827

3. The Core Principles Of Good Corporate Governance. URL: https://www.pearsetrust.ie/blog/bid/108866/the-core-principles-of-good-corporate-governance

4. G20/OECD Principles of Corporate Governance.URL: https://www.oecdilibrary.org/governance/g20_9789264252035-ru

5. International Standards for the Professional Practice of Internal Auditing. 2017 Edition. By The Institute of Internal Auditors, 247 Maitland Avenue, Altamonte Springs, Florrida 32701 - 4201, USA. All right reserved. URL: https://www.theiia.org/bookstore/ product/international-professional-practices-framework-2011-1533.cfm

6. Kvach Ya.P. Problems of corporate governance on the way to improving the economic security of the enterprise. Odessa: Economic space, 2015. № 98. P. 177-188. URL: http://nbuv.gov.ua/UJRN/ecpros_2015_98_19

7. Methodical recommendations on the organization of corporate governance in the banks of Ukraine. Approved by the decision of the Board of the NBU № 814-rsh from 03.12. 2018 URL: https://zakon.rada.gov.ua/laws/show

8. Moeller, Robert R. Brink's modern internal auditing : a common body of knowledge / Robert Moeller.7th ed.John Wiley \& Sons, Inc. 2009. 794 p.

9. Regulations on the organization of internal audit in banks of Ukraine, approved by the Resolution of the NBU № 311 of 10.05.2016 (as amended). URL: http://zakon.rada.gov.ua/laws/show/v0311500-16

10. Regulations on the organization of the risk management system in banks of Ukraine and banking groups, approved by the Resolution of the NBU Board № 64 dtd 11.06.2018 r. URL: https://zakon.rada.gov.ua/laws/show/v0064500-18\#n16

11. Polova O.L., Barda L.V. (2017) Organization of corporate governance system in the banking sector of Ukraine. Economy and state, № 9, pp. 34-38.

12. Principles of corporate governance for banks. Basel Committee on Banking Supervision. 08.07. 2015. URL: https://bank.gov.ua/document/download?docId= 64199632

13. Principles of corporate governance, approved by the National Commission on Securities and Stock Market of Ukraine from 12.03. 2020, № 118. URL: $\quad$ https://www.nssmc.gov.ua/documents/rshennya-pro-zatverdzhennya-printsipvkorporativnogo-upravlnnya/

14. Pickett K. H. Spencer.The internal auditing handbook. $2^{\text {nd }}$ edition. WILEY. 2003. 785 p. 